\title{
Acute-onset chorea and confusional state in 77-year-old COVID-19 patient: a case report
}

\author{
Katarzyna Sawczyńska ${ }^{1,2}$, Kamil Wężyk ${ }^{2,3}$, Magdalena Bosak ${ }^{1,2}$, Jeremiasz Jagiełła ${ }^{1,2}$, Szymon Andrasik ${ }^{2}$, \\ Alicja Kępińska-Wnuk ${ }^{1,2}$, Małgorzata Dec-Ćwiek ${ }^{1,2}$, Agnieszka Słowik ${ }^{1,2}$ \\ ${ }^{1}$ Department of Neurology, Jagiellonian University Medical College, Krakow, Poland \\ ${ }^{2}$ Department of Neurology, University Hospital in Krakow, Poland \\ ${ }^{3}$ Department of Physiotherapy, Jagiellonian University Medical College, Krakow, Poland
}

Key words: COVID-19, chorea, autoimmune encephalitis, involuntary movements

(Neurol Neurochir Pol 2022; 56 (1): 106-110)

\section{To the Editors}

SARS-CoV-2 has a proven neurotropic potential and can cause various neurological complications [1]. Involuntary movements represent a rare manifestation of COVID-19. We present a case report of COVID-19-associated chorea. This is to the best of our knowledge the first such case to be reported in a Polish population.

A 77-year-old woman was admitted to the University Hospital due to involuntary movements of acute onset. Two weeks before, she had received her first dose of COVID-19 mRNA vaccine. Soon afterwards, she had a close contact with a SARS-CoV2-infected person. Five days before admission, she developed disturbances in attention, consciousness, and cognition - she was hyperactive, occasionally delusional, and slight involuntary movements of the face appeared. On the next day, infection symptoms (i.e. cough, fever) also appeared. Her neurological condition worsened and fluctuated - involuntary movements spread to the limbs and a confusional state progressed. On admission, a routine COVID-19 antigen test from nasopharyngeal swab had been performed, confirming SARS-CoV-2 infection.

The patient had a history of arterial hypertension, diabetes mellitus, hypothyroidism, and urinary incontinence, and had three malignancies in remission (skin melanoma, thyroid and colon cancer). According to her family, for several months before her current deterioration she had required some help with everyday activities and had experienced slight problems with cognition. She did not take any medication with known potential to induce chorea (Tab. 1).

In neurological examination on admission, psychomotor slowing, orofacial dyskinesia and involuntary chorea-type movements of the trunk and all limbs (more pronounced on the left) were observed.

Non-contrast computed tomography (CT), CT angiography and perfusion $\mathrm{CT}$ of the brain were performed, showing no relevant abnormalities. Chest high-resolution CT revealed bilateral pneumonia (Fig. 1A). Head magnetic resonance imaging (MRI) (Fig. 1B) demonstrated marked features of cerebral small vessel disease - diffuse white matter hyperintensities, cortical and subcortical atrophy - with no acute ischaemic or contrast-enhancing lesions, nor oedema of the basal ganglia. Cerebrospinal fluid (CSF) and serum tests were unremarkable except for elevated serum inflammation markers (CRP $79.60 \mathrm{mg} / \mathrm{dL}$ ) and mild dyselectrolytemia $(\mathrm{Na}+134 \mathrm{mmol} / \mathrm{L}, \mathrm{K}+3.03 \mathrm{mmol} / \mathrm{L}, \mathrm{Ca} 2+$ $2.09 \mathrm{mmol} / \mathrm{L}$ ). Neuroinfection, hypoxic-ischaemic encephalopathy, metabolic, hormonal and autoimmune systemic diseases, paraneoplastic syndrome and prion disease were excluded. Antistreptolisin-O level was not elevated. Laboratory test results are summarised in Table 1. Electroencephalography (EEG) could not be performed on the COVID-19 ward.

A preliminary diagnosis of non-infectious encephalitis was made. Empirical treatment with steroids (methyloprednisolone $1 \mathrm{~g}$ i.v. per day for five days), symptomatic with diazepam and antiviral treatment with remdesivir (200 mg i.v. on day 1 , and $100 \mathrm{mg}$ i.v. for the following four days) were introduced,

Address for correspondence: Katarzyna Sawczynska, Jagiellonian University Medical College, Department of Neurology, Jakubowskiego 2, 30-688 Krakow, Poland; e-mail: katarzyna.sawczynska@gmail.com

Received: 4.10.2021 Accepted: 24.11.2021 Early publication date: 5.01.2022

This article is available in open access under Creative Common Attribution-Non-Commercial-No Derivatives 4.0 International (CC BY-NC-ND 4.0) license, allowing to download articles and share them with others as long as they credit the authors and the publisher, but without permission to change them in any way or use them commercially. 

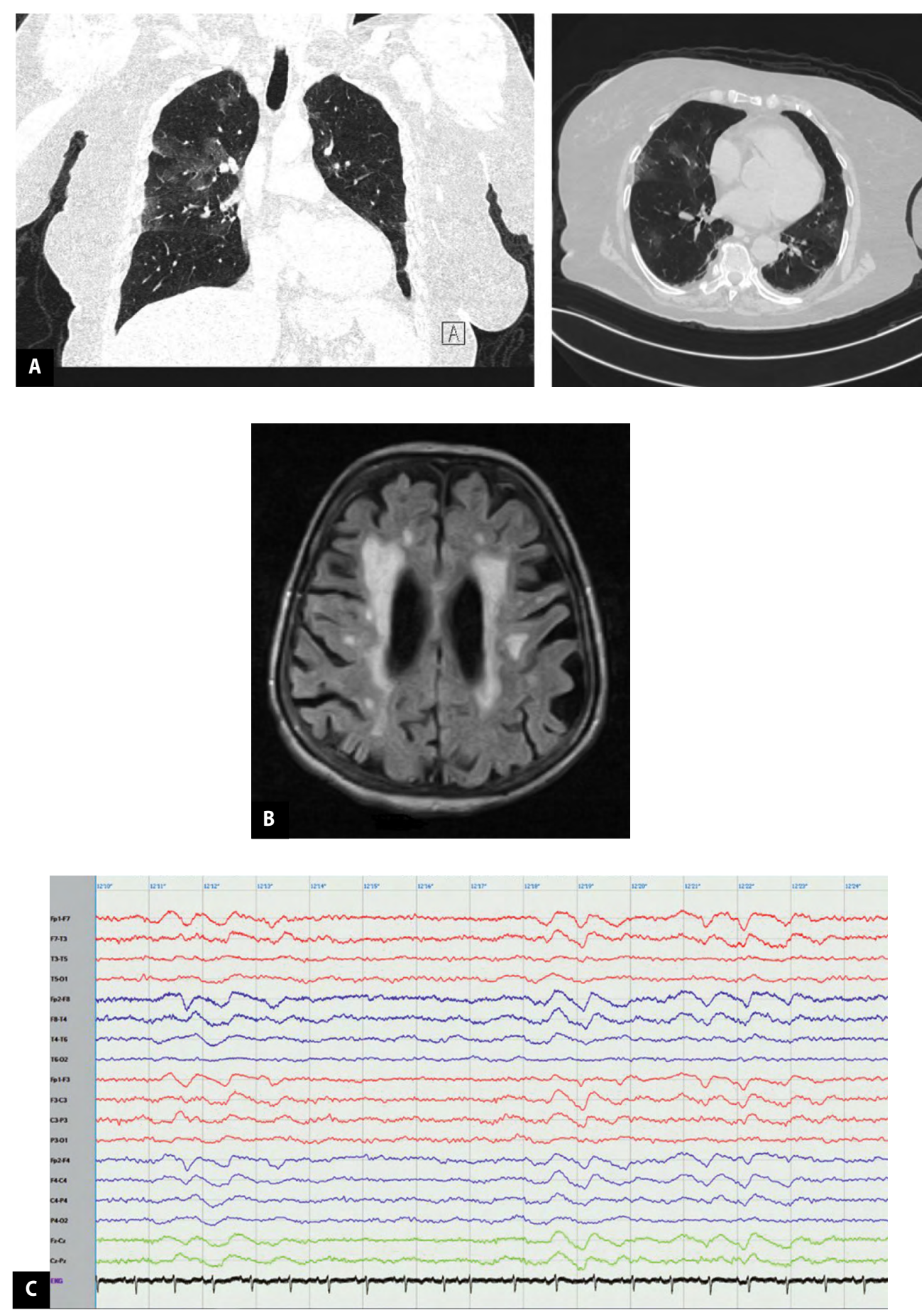

Figure 1. A. Chest high-resolution CT with bilateral pneumonia - distribution characteristic for SARS-CoV-2; B. Brain MRI: marked features of cerebral small vessel disease (CSVD), cortical and subcortical atrophy; C. EEG: frontal intermittent rhythmic delta activity (FIRDA) pattern. CT - computed tomography; EEG - electroencephalography; MRI - magnetic resonance imaging

with significant improvements - the involuntary movements disappeared and her mental status improved. After steroids and remdesivir were stopped, slight, fluctuating, chorea reappeared and left-sided hemiparesis and hemineglect were noted. A control MRI reconfirmed the absence of acute ischaemic and contrast-enhancing lesions. The symptoms were interpreted as inflammation progression and second line treatment with intravenous immunoglobulins (IVIG; $2 \mathrm{~g} / \mathrm{kg}$ over the course of five days) was started, with complete and permanent resolution of the chorea within the first days of therapy.

Having fulfilled the criteria for COVID-19 recovery, she was transferred to the General Neurology and Internal Medicine wards where further treatment and diagnostic tests were performed. During hospitalisation, 
Table 1. Differential diagnoses of involuntary movements in 77-year-old patient with COVID-19 infection

\begin{tabular}{|c|c|c|c|c|c|c|}
\hline Medications & $\begin{array}{l}\text { Infectious } \\
\text { encephalitis }\end{array}$ & $\begin{array}{l}\text { Autoimmune } \\
\text { encephalitis }\end{array}$ & $\begin{array}{l}\text { Systemic inflam- } \\
\text { matory and } \\
\text { autoimmune } \\
\text { disorders }\end{array}$ & $\begin{array}{l}\text { Metabolic } \\
\text { disorders }\end{array}$ & $\begin{array}{l}\text { Parenoplastic } \\
\text { syndrome }\end{array}$ & $\begin{array}{l}\text { Creutzfeldt- } \\
\text {-Jakob } \\
\text { Disease }\end{array}$ \\
\hline $\begin{array}{l}\text { No information } \\
\text { about involuntary } \\
\text { movements } \\
\text { in summaries } \\
\text { of product } \\
\text { characteristics } \\
\text { of the following } \\
\text { medications: } \\
\text { amlodipine, } \\
\text { indapamide, } \\
\text { perindopril, } \\
\text { bisoprolol, } \\
\text { metformin, } \\
\text { levothyroxine, } \\
\text { solifenacin, } \\
\text { azithromycin, } \\
\text { zolpidem }\end{array}$ & $\begin{array}{l}\text { CSF culture: } \\
\text { negative } \\
\text { Viral encephalitis } \\
\text { (screening } \\
\text { molecular tests for } \\
\text { CMV, HSV 1, HSV2, } \\
\text { VZV, Enterovirus, } \\
\text { parechovirus, } \\
\text { HSV6, HSV7, } \\
\text { parvovirus } \\
\text { B19, human } \\
\text { adenovirus): } \\
\text { negative } \\
\text { Bacterial } \\
\text { encephalitis } \\
\text { (screening } \\
\text { molecular tests } \\
\text { for Streptococcus } \\
\text { pneumoniae, } \\
\text { Haemophilus } \\
\text { influenzae, } \\
\text { Neisseria } \\
\text { meningitis): } \\
\text { negative } \\
\text { HIV infection: } \\
\text { HIV p24: negative } \\
\text { Syphilis: } \\
\text { RPR/VDRL: } \\
\text { negative } \\
\text { neuro-COVID: } \\
\text { SARS-CoV-2 PCR- } \\
\text { RT test: negative } \\
\text { Neuroborreliosis: } \\
\text { IgG, IgM Borrelia } \\
\text { serum (ELISA test): } \\
\text { negative } \\
\text { IgG, IgM Borrelia- } \\
\text { CSF (ELISA test): } \\
\text { negative } \\
\text { Tick-Borne } \\
\text { Encephalitis: IgM- } \\
\text { TBE: negative }\end{array}$ & 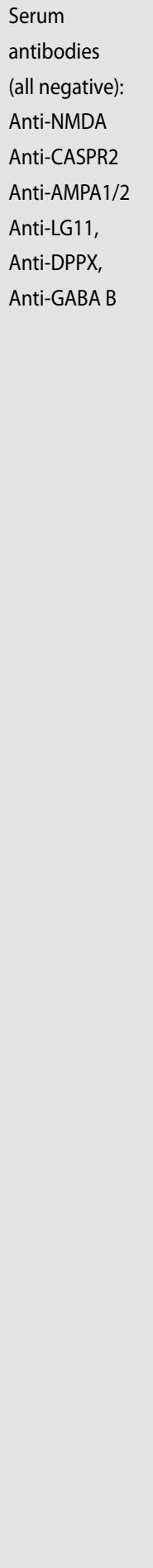 & $\begin{array}{l}\text { Antinuclear } \\
\text { antibodies (ANA): } \\
\text { speckled (s-ANA) } \\
\text { 1:320 titre, } \\
\text { Nucleolar (N-ANA) } \\
\text { 1:640 titre, } \\
\text { Cytoplasmic } \\
\text { (C-ANA) 1:160 } \\
\text { titre; } \\
\text { Immunoblot ANA } \\
\text { Profile + DFS70 } \\
\text { (all negative): } \\
\text { Anti-Ku, Anti- } \\
\text { Mi-2, Anti-nRNP, } \\
\text { Anti-Sm, Anti-SSA, } \\
\text { Anti-SSB, Anti- } \\
\text { Scl-70, Anti-Jo-1, } \\
\text { Anti-Ro-52, } \\
\text { Anti-PM-Scl 100, } \\
\text { Anti-Centromer } \\
\text { B, Anti-PCNA, } \\
\text { Anti-dsDNA, } \\
\text { Anti-Nucleosome, } \\
\text { Anti-Histone, } \\
\text { Anti-ribosomal } \\
\text { protein P, Anti- } \\
\text { mitochondria-M2, } \\
\text { Anti-DFS70, } \\
\text { Lupus } \\
\text { anticoagulant } \\
\text { (LA): negative } \\
\text { Anti-streptolysin } \\
\text { O titre } \\
\text { 116.00 IU/mL } \\
\text { [<200] }\end{array}$ & $\begin{array}{l}\text { Electrolyte } \\
\text { imbalance: } \\
\text { serum potassium: } \\
\text { hypocalemia at } \\
\text { admission } \\
\text { (2.7 mmol/L) } \\
\text { serum sodium: } \\
\text { mild hyponatremia } \\
\text { at admission (134 } \\
\text { mmol/L) } \\
\text { serum calcium: } \\
\text { mild hypocalcemia } \\
\text { on first days of } \\
\text { hospitalisation } \\
\text { (2.09 mmol/L) } \\
\text { serum magnesium: } \\
\text { normal (0.78 } \\
\text { mmol/L) } \\
\text { Hypo-/ } \\
\text { hyperthyroidism: } \\
\text { TSH 2.890 ulU/mL } \\
\text { [0.270-4.200] } \\
\text { Hypo-/ } \\
\text { hyperparathyroidism: } \\
\text { PTH 18.3 pg/mL } \\
\text { [14.90-56.90] } \\
\text { Vitamin B12 } \\
\text { deficiency: } \\
\text { hypervitaminosis, } \\
\text { B12 level: 1,067.0 pg/ } \\
\text { mL [191.0-663.0] } \\
\text { Hepatic disease: } \\
\text { AST, ALT: normal } \\
\text { HBsAg, anti-HCV: } \\
\text { negative }\end{array}$ & $\begin{array}{l}\text { Whole-body CT } \\
\text { (head, chest, } \\
\text { abdomen and } \\
\text { pelvis): no tumour } \\
\text { detected } \\
\text { Gastroscopy and } \\
\text { colonoscopy: no } \\
\text { tumour detected } \\
\text { Bronchoscopy: no } \\
\text { tumour detected } \\
\text { Paraneoplastic } \\
\text { antibodies serum } \\
\text { (all negative): } \\
\text { anti-Amphiphysin, } \\
\text { anti-CV2, anti- } \\
\text { PNMA2 (Ma2/Ta), } \\
\text { anti-Ri (Nova1), } \\
\text { anti-Yo (cdr62), } \\
\text { anti-Hu (HuD), } \\
\text { anti-Recoverin, } \\
\text { anti-SOX1, anti- } \\
\text { Titin, anti-Zic4, } \\
\text { anti-GAD65, anti- } \\
\text { Tr (DNER) }\end{array}$ & $\begin{array}{l}\text { 14-3-3 protein: } \\
\text { negative } \\
\text { RT-Quick: } \\
\text { negative } \\
\text { Brain-MRI: } \\
\text { no typical } \\
\text { imaging findings }\end{array}$ \\
\hline
\end{tabular}

several episodes of transient loss of consciousness (lasting for a few minutes) occurred. These were interpreted as symptomatic seizures secondary to encephalitis, and therefore antiepileptic treatment was introduced.
Electroencephalography showed a frontal intermittent rhythmic delta activity (FIRDA) pattern (Fig. 1C). Control MRI imaging was stable, and CSF examinations were unremarkable. 
Thepatient required prolonged hospitalisation due to multiple non-neurological complications - new onset atrial fibrillation, bacterial pneumonia, urinary tract infection, sepsis, pulmonary embolism, and reactive arthritis. Involuntary movements have not reappeared during a three-month follow up. Left-sided hemiparesis was persistent (with intensity depending on the patient's general condition).

Chorea has only rarely been reported as a manifestation of COVID-19. A literature review by Brandão et al. [2] identified 93 cases of new-onset movement disorders in COVID-19 patients, with the most common of these being myoclonus $(63.4 \%)$ and only one case of chorea. In a recent systematic review by Hirschfeld [3], among 49 cases of hyperkinetic movement disorders in adult, non-intubated COVID-19 patients without a pre-existent movement disorder or organic brain injury, the most common one was ataxia (83.67\%); no cases of chorea were included. Ataxia-myoclonus syndrome has emerged as a complication of COVID-19 infection, and two cases were reported in Poland by Przytuła et al. [4]. In a prospective study by Ray et al. [8] on the prevalence of COVID-19 neurological manifestations among 1,334 children, two cases of acute chorea were reported. Byrnes et al. [9], Hassan et al. [5] and Cotta Ramusino et al. [10] reported COVID-19-associated chorea in adults, most probably due to non-infectious encephalitis. Ghosh et al. [11] reported a case of chorea in the course of diabetic ketoacidosis triggered by SARS-CoV-2 infection. Yüksel et al. [12] and DeVette et al. [13] reported cases of chorea in children with COVID-19 - with either a history of Sydenham's chorea or a concomitant streptococcal infection. We found no literature report of new onset involuntary movements developing after COVID-19 mRNA vaccine in patients without a pre-existent movement disorder.

Brandão et al. [2] reviewed diagnostic test results in patients with COVID-19-associated movement disorders. $72.7 \%$ of available brain MRIs showed no abnormalities or non-related findings. From available CSF analyses, pleocytosis was present in $26.7 \%$ and slightly elevated protein in $49.9 \%$ of cases. Among available EEG results, abnormalities appeared in $76.7 \%$ (most commonly background slowing - in 59.3\%).

Several studies have evaluated EEG abnormalities in patients with COVID-19 encephalopathy. In their meta-analysis, Kubota et al. [14] reported that abnormal background activity and generalised slowing are common $(96.1 \%$ of analysed patients), although they occur in many different encephalopathies. In our patient, we recorded FIRDA, a pattern that can result from several potential aetiologies, including metabolic and hypoxic encephalopathy, neurodegenerative disease, systemic infection, and encephalitis [14]. In their systemic review, Antony and Haneef [6] demonstrated, however, that frontal EEG patterns (i.e. focal slowing, periodic discharges and rhythmic delta activity) are characteristic of COVID-19 encephalopathy.
The differential diagnosis of acute-onset chorea is wide, including vascular, metabolic, infectious, post-infectious, paraneoplastic, autoimmune, and medication-induced disorders [7]. In our patient, COVID-19-associated autoimmune encephalitis seems to be the most probable cause of chorea. There was an evident time correlation between the onset of involuntary movement and the beginning of SARS-CoV-2 infection, and a marked improvement after immunosuppressive therapy and infection treatment.

It is significant that when treatment with steroids was stopped, fluctuating chorea reappeared and our patient required second line treatment with IVIG. We found no other possible causes of chorea except for dyselectrolytemia, although this is less likely due to the lack of severity and the lack of a time correlation between its treatment and the intensity of involuntary movements.

\section{Conflict of interest: None.}

Funding: None.

\section{References}

1. Collantes ME, Espiritu Al, Sy MC, et al. Neurological manifestations in COVID-19 infection: a systematic review and meta-analysis. Can J Neurol Sci. 2021; 48(1): 66-76, doi: 10.1017/cjn.2020.146, indexed in Pubmed: 32665054.

2. Brandão PR, Grippe TC, Pereira DA, et al. New-onset movement disorders associated with COVID-19. Tremor Other Hyperkinet Mov (N Y). 2021; 11: 26, doi: 10.5334/tohm.595, indexed in Pubmed: 34277139.

3. Hirschfeld AS. Autoimmune mediated hyperkinetic movement disorders in SARS-CoV-2 infection - a systematic review. Neurol Neurochir Pol. 2021 [Epub ahead of print], doi: 10.5603/PJNNS.a2021.0069, indexed in Pubmed: 34637137.

4. Przytuła F, Błądek S, Sławek J. Two COVID-19-related video-accompanied cases of severe ataxia-myoclonus syndrome. Neurol Neurochir Pol. 2021; 55(3): 310-313, doi: 10.5603/PJNNS.a2021.0036, indexed in Pubmed: 34096013.

5. Hassan M, Syed F, Ali L, et al. Chorea as a presentation of SARSCoV-2 encephalitis: a clinical case report. J Mov Disord. 2021; 14(3): 245-247, doi: 10.14802/jmd.20098, indexed in Pubmed: 33706477.

6. Antony AR, Haneef Z. Systematic review of EEG findings in 617 patients diagnosed with COVID-19. Seizure. 2020; 83: 234-241, doi: 10.1016/j.seizure.2020.10.014, indexed in Pubmed: 33121875.

7. Walker RH. Differential diagnosis of chorea. Curr Neurol Neurosci Rep. 2011; 11(4): 385-395, doi: 10.1007/s11910-011-0202-2, indexed in Pubmed: 21465146.

8. Ray S, Abdel-Mannan O, Sa M, et al. Neurological manifestations of SARS-CoV-2 infection in hospitalised children and adolescents in the UK: a prospective national cohort study. Lancet Child Adolesc Health. 2021; 5(9): 631-641, doi: 10.1016/s2352-4642(21)00193-0, indexed in Pubmed: 34273304.

9. Byrnes S, Bisen M, Syed B, et al. COVID-19 encephalopathy masquerading as substance withdrawal. J Med Virol. 2020; 92(11): 23762378, doi: 10.1002/jmv.26065, indexed in Pubmed: 32458578. 
10. Cotta Ramusino M, Perini G, Corrao G, et al. SARS-CoV-2 in a patient with acute chorea: innocent bystander or unexpected actor? Mov Disord Clin Pract. 2021; 8(6): 950-953, doi: 10.1002/mdc3.13274, indexed in Pubmed: 34405104.

11. Ghosh R, Dubey S, Roy D, et al. Choreo-ballistic movements heralding COVID-19 induced diabetic ketoacidosis. Diabetes Metab Syndr. 2021; 15(3): 913-917, doi: 10.1016/j.dsx.2021.04.010, indexed in Pubmed: 33915346.

12. Yüksel MF, Yıldırım M, Bektaş Ö, et al. A sydenham chorea attack associated with COVID-19 infection. Brain Behav Immun Health. 2021; 13: 100222, doi: 10.1016/j.bbih.2021.100222, indexed in Pubmed: 33615279 .
13. DeVette $\mathrm{Cl}$, Ali CS, Hahn DW, et al. Acute rheumatic fever in a COVID-19-positive pediatric patient. Case Rep Pediatr. 2021; 2021: 6655330, doi: 10.1155/2021/6655330, indexed in Pubmed: 33936829

14. Kubota T, Gajera PK, Kuroda N. Meta-analysis of EEG findings in patients with COVID-19. Epilepsy Behav. 2021; 115: 107682, doi: 10.1016/j.yebeh.2020.107682, indexed in Pubmed: 33342709.

15. Kim KT, Roh YN, Cho NH, et al. Clinical correlates of frontal intermittent rhythmic delta activity without structural brain lesion. Clin EEG Neurosci. 2021; 52(1): 69-73, doi: 10.1177/1550059420922741, indexed in Pubmed: 32412802. 